\title{
Longterm Data on Sirolimus Treatment in Patients with Lupus Nephritis
}

\author{
Desmond Y.H. Yap ${ }^{(\mathbb{D})}$, Colin Tang, Gary C.W. Chan, Lorraine P.Y. Kwan, Maggie K.M. Ma, \\ Maggie M.Y. Mok, and Tak Mao Chan
}

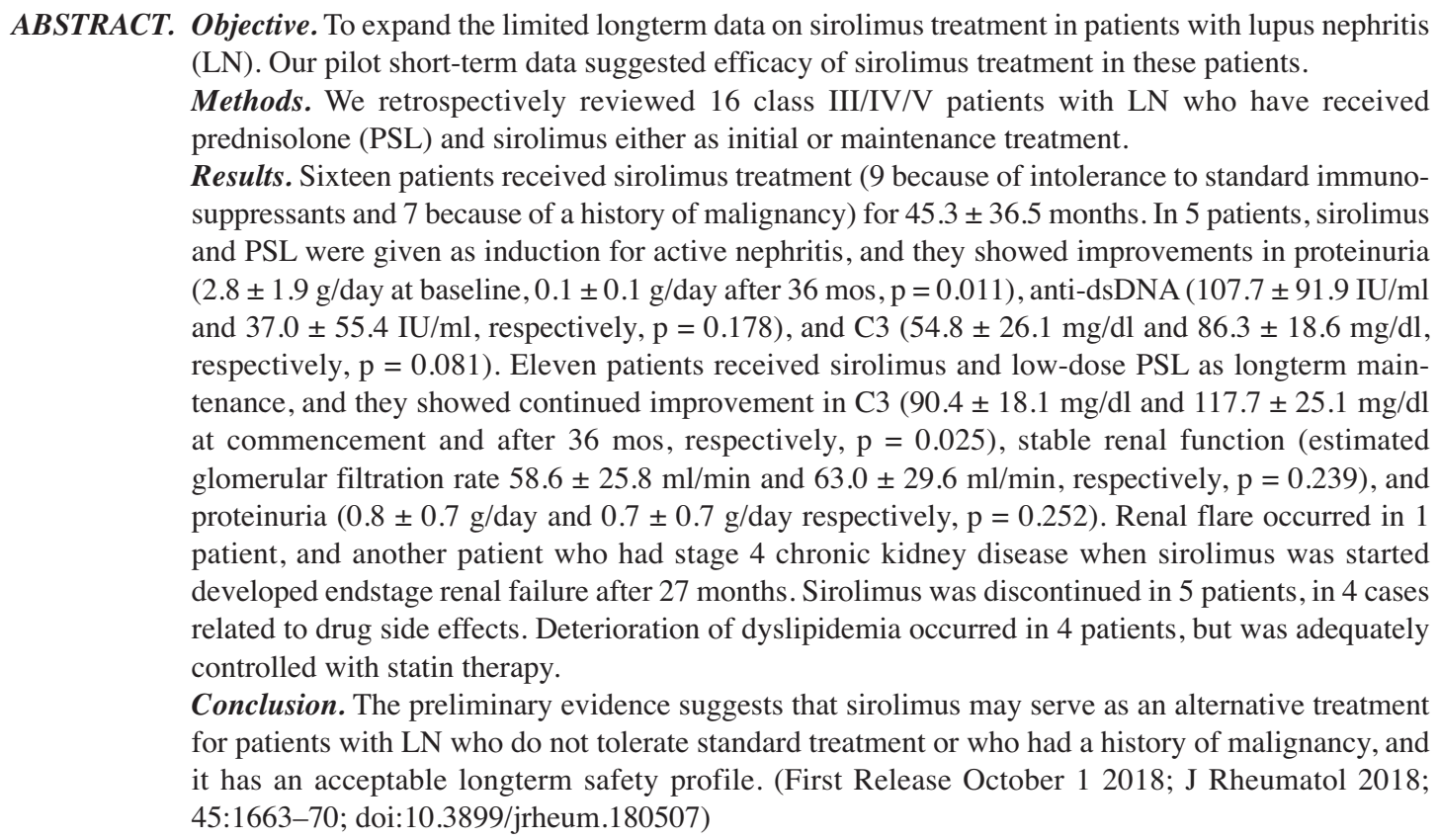

Key Indexing Terms:

SIROLIMUS MALIGNANCY LUPUS NEPHRITIS LONGTERM TREATMENT

Lupus nephritis (LN) is a serious organ complication in patients with systemic lupus erythematosus (SLE), and is associated with excessive patient mortality ${ }^{1,2}$. LN can occur in about $50 \%$ of white patients with SLE, and up to $60-70 \%$ in Asian patients with $\mathrm{SLE}^{1,2,3}$. The disease course of $\mathrm{LN}$ is

From the Division of Nephrology, Department of Medicine, Queen Mary Hospital, The University of Hong Kong, Hong Kong.

D.Y. Yap, MD, FRCP, Division of Nephrology, Department of Medicine, Queen Mary Hospital, The University of Hong Kong; C. Tang, BSc, Division of Nephrology, Department of Medicine, Queen Mary Hospital, The University of Hong Kong; G.C. Chan, FHKCP, Division of Nephrology, Department of Medicine, Queen Mary Hospital, The University of Hong Kong; L.P. Kwan, FHKCP, Division of Nephrology, Department of Medicine, Queen Mary Hospital, The University of Hong Kong; M.K. Ma, FRCP, Division of Nephrology, Department of Medicine, Queen Mary Hospital, The University of Hong Kong; M.M. Mok, FHKCP, Division of Nephrology, Department of Medicine, Queen Mary Hospital,

The University of Hong Kong; T.M. Chan, MD, FRCP, Division of Nephrology, Department of Medicine, Queen Mary Hospital, The University of Hong Kong.

Address correspondence to Prof. Tak Mao Chan, Department of Medicine, Queen Mary Hospital, 102 Pokfulam Road, The University of Hong Kong, Hong Kong.E-mail:dtmchan@hku.hk

Accepted for publication June 28, 2018. characterized by episodes of active renal flares between periods of disease quiescence. The disease state is usually determined by renal [e.g., proteinuria, estimated glomerular filtration rate (eGFR), serum creatinine] and SLE serological variables (e.g., anti-dsDNA and C3 levels). Active LN usually presents with nephrotic-range proteinuria and with or without active urine sediments and renal dysfunction, and is often accompanied by active SLE serology. Disease quiescence is denoted by low-grade/absence of proteinuria and inactive urinary sediments, and is often associated with quiescent serological markers. The current standard-of-care induction treatments for active severe LN are corticosteroids combined with either cyclophosphamide (CYC) or mycophenolate mofetil (MMF), followed by low-dose corticosteroids plus either MMF or azathioprine (AZA) maintenance to prevent relapse $4,5,6,7,8$. While these immunosuppressive regimens have established short- and longterm efficacy for the treatment of $\mathrm{LN}$, each agent is associated with potential toxicities, and thus there is always a keen demand for novel therapeutic agents to facilitate tailoring treatment according to the distinct needs of individual patients ${ }^{9,10,11,12}$.

Personal non-commercial use only. The Journal of Rheumatology Copyright @ 2018 . All rights reserved. 
Sirolimus is a mammalian target of rapamycin (mTOR) inhibitor and has pleotropic actions that include immunosuppressive, antiproliferative, and antifibrotic effects ${ }^{13}$. The current clinical uses of mTOR inhibitors include the prevention of organ transplantation rejection and treatment of advanced neoplasms ${ }^{13,14,15}$. By virtue of its immunosuppressive mechanisms, it is speculated that sirolimus can also serve as a therapy for LN. In this context, previous animal studies from our group and other investigators have demonstrated that sirolimus could delay the onset of renal manifestations and could also ameliorate established nephritis in $N Z B / W F 1$ mice $^{16,17,18,19}$. Early studies have reported that sirolimus could improve disease activity scores in 9 patients with active SLE (2 with renal involvement) who were refractory to standard immunosuppressive treatments ${ }^{20}$. We have also reported pilot short-term data on mTOR inhibitors in the treatment of patients with $\mathrm{LN}^{21}$. However, that series involved only 7 patients with treatment duration of 17 to 37 months. We hereby report a retrospective study on the efficacy and safety of mTOR inhibitor treatment in 16 patients with $\mathrm{LN}$ who received this treatment for about 4 years.

\section{MATERIALS AND METHODS}

The case records of patients with LN who attended the SLE Clinic at Queen Mary Hospital from January 2007 to January 2016 were reviewed. Our study was approved by the University of Hong Kong/Hospital Authority West Cluster Institutional Review Board (approval number: UW11-115). Patients with class III $\pm \mathrm{V}$ or IV $\pm \mathrm{V}$ or pure class V LN (defined according to the International Society of Nephrology/Renal Pathology Society 2003 classification) who had been treated with sirolimus were included in this retrospective study. In our center, the first-line treatment for proliferative LN (i.e., class III $\pm \mathrm{V}$ or IV $\pm \mathrm{V} \mathrm{LN}$ ) was prednisolone (PSL) combined with MMF for induction followed by low-dose PSL plus either MMF or AZA as maintenance immunosuppression ${ }^{8,11,12}$. CYC was reserved for patients with severe crescentic features in the kidney biopsy. Calcineurin inhibitors (CNI) were used as second-line treatment in patients who could not tolerate MMF, or as add-on therapy in patients who showed persistent significant proteinuria (>2 g/day) despite standard therapy for 6 months ${ }^{22}$. Sirolimus was used in patients who could not tolerate standard immunosuppressants or who had a history of malignancy. During the induction phase, oral PSL was commenced at $0.8 \mathrm{mg} / \mathrm{kg} / \mathrm{day}$ and tapered by $5 \mathrm{mg} /$ day every fortnight to a maintenance dose of 5-7.5 mg/day at about 5 months. Sirolimus, when used during active nephritis, was commenced at $5 \mathrm{mg}$ on the first day and followed by $2 \mathrm{mg} / \mathrm{day}$. The sirolimus dose was adjusted to aim for target trough blood levels of $6-8 \mu \mathrm{g} / \mathrm{l}$. When used as maintenance immunosuppression in patients with quiescent disease, sirolimus was initiated at $1 \mathrm{mg} /$ day and titrated to achieve a trough level of 4-6 $\mu \mathrm{g} / \mathrm{l}$. The initial dosages of sirolimus were reduced by half in patients who also received concomitant diltiazem treatment.

Patients were followed at 2 weeks, 4 weeks, and then every 12 weeks. Variables monitored during each clinic visit were complete blood count, liver and renal functions, anti-dsDNA, serum C3/4, 12-h trough sirolimus levels, and urinary protein. Any clinically significant events and side effects were documented. Lipids (total cholesterol, triglyceride, and low-density lipoprotein cholesterol levels) and glycemic profiles (fasting glucose and HbA1c) were measured at 6-month intervals.

Statistical analysis. Continuous variables are expressed as mean (SD) or median (range), and analyzed by Student $t$ test or Mann-Whitney test, where appropriate. Categorical variables were expressed as frequencies (percen- tages) and analyzed by chi-square test or Fisher's exact test, where appropriate. All statistical analyses were performed using SAS statistical software version 9.1 (SAS Institute Inc.), and p values $<0.05$ were considered statistically significant.

\section{RESULTS}

Sirolimus dose and trough level. Sixteen patients with LN were included ( 5 started taking sirolimus during active LN and 11 during disease quiescence; Table 1 and Table 2). The duration of sirolimus treatment was $45.3 \pm 36.5$ months. Nine patients received sirolimus because of intolerance to standard immunosuppressants ( 6 related to MMF and 3 related to CNI intolerance), and 7 because of a history of malignancy ( 2 had renal cell carcinoma, 2 breast cancer, 1 salivary gland carcinoma, 1 ovarian cancer, and 1 vulval carcinoma). For patients who received PSL and sirolimus as continuous induction-maintenance treatment, the actual dose at 6,12, 24, and $36 \mathrm{months}$ was $2.0 \pm 1.0 \mathrm{mg} / \mathrm{day}, 1.8 \pm 1.3 \mathrm{mg} / \mathrm{day}, 1.8$ $\pm 1.3 \mathrm{mg} / \mathrm{day}$, and $1.8 \pm 0.8 \mathrm{mg} /$ day, respectively. The corresponding 12-h trough sirolimus levels were $6.7 \pm 0.9 \mu \mathrm{g} / \mathrm{l}$, $4.4 \pm 1.7 \mu \mathrm{g} / \mathrm{l}, 4.2 \pm 1.6 \mu \mathrm{g} / \mathrm{l}$, and $4.2 \pm 0.6 \mu \mathrm{g} / \mathrm{l}$, respectively. Two patients who received sirolimus induction also received concomitant diltiazem treatment, but their sirolimus was discontinued at $5.0 \pm 1.4$ months (the sirolimus dosage was

Table 1. Clinical characteristics of 16 lupus nephritis (LN) patients who had received prednisolone and sirolimus treatment.

\begin{tabular}{lc}
\hline Age, yrs & $49.0 \pm 7.8$ \\
\hline Sex, F/M & $15: 1$ \\
Duration of SLE before sirolimus treatment, mos & $204.6 \pm 113.7$ \\
Class of LN & \\
Class III \pm V or Class IV \pm V & 14 \\
Class V & 2 \\
Immunosuppressive regimen prior to sirolimus treatment & \\
PSL + MMF & 4 \\
PSL + AZA & 4 \\
PSL + CNI & 3 \\
PSL alone & 4 \\
None & 1 \\
Indications for sirolimus treatment & 7 \\
Malignancy & 6 \\
Intolerance to MMF & 3 \\
Intolerance to CNI & \\
Clinical variables before initiation of sirolimus treatment & $114.2 \pm 15.1$ \\
Systolic blood pressure, mmHg & $70.8 \pm 10.6$ \\
Diastolic blood pressure, mmHg & $58.6 \pm 25.8$ \\
eGFR, ml/min/1.73 m ${ }^{2}$ & $1.8 \pm 1.7$ \\
Urine protein excretion, g/day & $65.6 \pm 72.8$ \\
Anti-dsDNA, IU/ml & $77.1 \pm 27.2$ \\
Serum C3, mg/dl & $4.5 \pm 0.4$ \\
Fasting glucose, mmol/1 & $5.1 \pm 0.8$ \\
Total cholesterol, mmol/l & $2.8 \pm 0.8$ \\
LDL cholesterol, mmol/l & $1.4 \pm 0.9$ \\
Triglyceride, mmol/1 & \\
\hline
\end{tabular}

SLE: systemic lupus erythematosus; AZA: azathioprine; CNI: calcineurin inhibitors; MMF: mycophenolate mofetil; PSL: prednisolone; eGFR: estimated glomerular filtration rate; LDL: low-density lipoprotein. 
Table 2. Treatment details and outcomes of 16 patients with lupus nephritis (LN) who received sirolimus during active nephritis or disease quiescence.

\begin{tabular}{|c|c|c|c|c|c|c|c|c|}
\hline \multicolumn{9}{|c|}{ Patients who received sirolimus during active disease } \\
\hline Patient & $\begin{array}{l}\text { Tx for LN } \\
\text { Before } \\
\text { Sirolimus }\end{array}$ & $\begin{array}{l}\text { Response } \\
\text { to Previous } \\
\text { Tx }\end{array}$ & $\begin{array}{l}\text { Indication } \\
\text { of } \\
\text { Sirolimus }\end{array}$ & $\begin{array}{l}\text { Duration } \\
\quad \text { of } \\
\text { Sirolimus }\end{array}$ & $\begin{array}{l}\text { Dose of } \\
\text { Concomitant } \\
\text { PSL }\end{array}$ & $\begin{array}{l}\text { Mean } \\
\text { Achieved } \\
\text { Sirolimus } \\
\text { Dosage }\end{array}$ & $\begin{array}{l}\text { Mean 12-h } \\
\text { Trough } \\
\text { Sirolimus } \\
\text { Level, } \mu \mathrm{g} / 1\end{array}$ & Key Outcomes \\
\hline $1 *$ & - & - & $\begin{array}{l}\text { History of } \\
\text { malignancy }\end{array}$ & 8 weeks & $35 \mathrm{mg} /$ day & $1 \mathrm{mg} /$ day & $2.9 \pm 0.1$ & $\begin{array}{l}\text { Tx discontinuation because of rash; } \\
\text { switched to PSL + FK after stopping } \\
\text { sirolimus. One episode of hematological flare. } \\
\text { No recurrence of malignancy. }\end{array}$ \\
\hline 2 & $\mathrm{PSL}+\mathrm{MMF}$ & PR & MMF intolerance & $84 \operatorname{mos}$ & $40 \mathrm{mg} /$ day & $1 \mathrm{mg} /$ day & $6.1 \pm 3.2$ & Achieved CR; no clinical relapse. \\
\hline $3 *$ & - & - & $\begin{array}{l}\text { History of } \\
\text { malignancy }\end{array}$ & $82 \operatorname{mos}$ & $50 \mathrm{mg} /$ day & $2 \mathrm{mg} /$ day & $6.0 \pm 2.5$ & $\begin{array}{l}\text { Achieved CR; no clinical relapse or recurrence of } \\
\text { malignancy. }\end{array}$ \\
\hline 4 & $\mathrm{PSL}+\mathrm{MMF}$ & PR & MMF intolerance & 10 weeks & $40 \mathrm{mg} /$ day & $1 \mathrm{mg} /$ day & $7.7 \pm 0.6$ & $\begin{array}{l}\text { Tx discontinuation because of cholecystitis. } \\
\text { Switched to PSL + AZA after stopping sirolimus. } \\
\text { ESRF after } 27 \text { mos. }\end{array}$ \\
\hline
\end{tabular}

Patients who received sirolimus during disease quiescence

\begin{tabular}{|c|c|c|c|c|c|c|}
\hline Patient & $\begin{array}{c}\text { Indication } \\
\text { of } \mathrm{Tx}\end{array}$ & $\begin{array}{c}\text { Duration } \\
\text { of } T x\end{array}$ & $\begin{array}{c}\text { Dose of } \\
\text { Concomitant } \\
\text { PSL }\end{array}$ & $\begin{array}{c}\text { Mean } \\
\text { Achieved } \\
\text { Sirolimus } \\
\text { Dosage }\end{array}$ & $\begin{array}{l}\text { Mean 12-h } \\
\text { Trough } \\
\text { Sirolimus } \\
\text { Level, } \mu \mathrm{g} / 1\end{array}$ & Key Outcomes \\
\hline
\end{tabular}

\begin{tabular}{|c|c|c|c|c|c|c|}
\hline 6 & MMF intolerance & $110 \mathrm{mos}$ & $5 \mathrm{mg} /$ day & $1 \mathrm{mg} / \mathrm{day}$ & $3.9 \pm 0.4$ & No clinical relapse. \\
\hline 7 & MMF intolerance & 11 weeks & $5 \mathrm{mg} /$ day & $1 \mathrm{mg} /$ day & $3.7 \pm 0.1$ & Tx discontinuation because of headache. \\
\hline 8 & History of malignancy & $65 \operatorname{mos}$ & $4 \mathrm{mg} /$ day & $1 \mathrm{mg} / \mathrm{day}$ & $3.5 \pm 0.6$ & No clinical relapse or recurrence of malignancy. \\
\hline 9 & FK intolerance & 11 weeks & $5 \mathrm{mg} /$ day & $1 \mathrm{mg} /$ day & $<2.0$ & Tx discontinuation because of rash. \\
\hline 11 & MMF intolerance & $56 \mathrm{mos}$ & $7.5 \mathrm{mg} /$ day & $1 \mathrm{mg} /$ day & $3.7 \pm 2.0$ & No clinical relapse. \\
\hline 12 & FK intolerance & $48 \mathrm{mos}$ & $6 \mathrm{mg} /$ day & $1 \mathrm{mg} / \mathrm{day}$ & $3.3 \pm 0.4$ & No clinical relapse. \\
\hline 13 & History of malignancy & $48 \mathrm{mos}$ & $2.5 \mathrm{mg} /$ day & $1 \mathrm{mg} /$ day & $3.9 \pm 0.3$ & No clinical relapse or recurrence of malignancy. \\
\hline 16 & MMF intolerance & $36 \mathrm{mos}$ & $9 \mathrm{mg} /$ day & $1 \mathrm{mg} / \mathrm{day}$ & $2.6 \pm 0.8$ & $\begin{array}{l}\text { One episode of renal relapse; Tx discontinuation } \\
\text { because of leukopenia. }\end{array}$ \\
\hline
\end{tabular}

*Patients 1 and 3 received sirolimus as their first treatment for LN because of their history of malignancy. AZA: azathioprine; CR: complete remission; ESRF: endstage renal failure; FK: tacrolimus; MMF: mycophenolate mofetil; PR: partial remission; PSL: prednisolone.

$2.0 \pm 0.0 \mathrm{mg} /$ day at the time of sirolimus discontinuation, and the corresponding 12-h trough levels were $7.7 \mu \mathrm{g} / \mathrm{l}$ and $2.9 \mu \mathrm{g} / \mathrm{l}$, respectively). For patients who began sirolimus during disease quiescence, the actual dose was $1.3 \pm 0.5$ $\mathrm{mg} / \mathrm{day}, 1.2 \pm 0.5 \mathrm{mg} / \mathrm{day}, 1.3 \pm 0.6 \mathrm{mg} / \mathrm{day}$, and $1.3 \pm 0.5$ $\mathrm{mg} / \mathrm{day}$, after $6,12,24$, and 36 months, respectively, and the corresponding 12-h trough levels were $4.5 \pm 1.4 \mu \mathrm{g} / \mathrm{l}$, $4.0 \pm 1.7 \mu \mathrm{g} / \mathrm{l}, 4.0 \pm 1.2 \mu \mathrm{g} / \mathrm{l}$, and $3.9 \pm 0.9 \mu \mathrm{g} / \mathrm{l}$, respectively. Two patients who were treated with sirolimus during maintenance phase also received concomitant diltiazem.

Renal outcomes. Treatment of active LN with PSL and sirolimus was associated with progressive reduction of proteinuria over time $(2.8 \pm 1.9 \mathrm{~g} / \mathrm{day}, 2.1 \pm 1.4 \mathrm{~g} / \mathrm{day}, 0.5 \pm$ $0.3 \mathrm{~g} / \mathrm{day}, 0.2 \pm 0.1 \mathrm{~g} / \mathrm{day}$, and $0.1 \pm 0.1 \mathrm{~g} /$ day at baseline and after $6,12,24$, and 36 months of treatment; $p=0.064,0.063$, 0.063 , and 0.011 compared with baseline, respectively;
Figure 1A). Improvement in eGFR was also observed (58.8 $\pm 29.1 \mathrm{ml} / \mathrm{min} / 1.73 \mathrm{~m}^{2}, 75.3 \pm 14.0 \mathrm{ml} / \mathrm{min} / 1.73 \mathrm{~m}^{2}$, $87.3 \pm 4.5 \mathrm{ml} / \mathrm{min} / 1.73 \mathrm{~m}^{2}, 73.7 \pm 14.6 \mathrm{ml} / \mathrm{min} / 1.73 \mathrm{~m}^{2}$, and $79.0 \pm 9.8 \mathrm{ml} / \mathrm{min} / 1.73 \mathrm{~m}^{2}$ at baseline and after $6,12,24$, and 36 months of treatment; $\mathrm{p}=0.013,0.066,0.039$, and 0.078 compared with baseline, respectively; Figure 1B). Two patients (patients 1 and 4) discontinued sirolimus at 8 and 10 weeks, respectively (Table 2). Patient 1 responded to PSL and tacrolimus after stopping sirolimus; the proteinuria levels were $0.3 \mathrm{~g} /$ day, $0.1 \mathrm{~g} /$ day, $0.1 \mathrm{~g} /$ day, and $0.3 \mathrm{~g} /$ day after $6,12,24$, and 36 months, respectively. Patient 4 received PSL and AZA after discontinuation of sirolimus, but developed progressive renal failure despite achieving serological quiescence. Her proteinuria levels were $2.0 \mathrm{~g} /$ day, $1.2 \mathrm{~g} /$ day, $0.7 \mathrm{~g} /$ day, and 0.4 $\mathrm{g}$ /day, after 6, 12, 24, and 36 months, respectively.

In patients who were treated with sirolimus during disease

Personal non-commercial use only. The Journal of Rheumatology Copyright $\subset$ 2018. All rights reserved. 

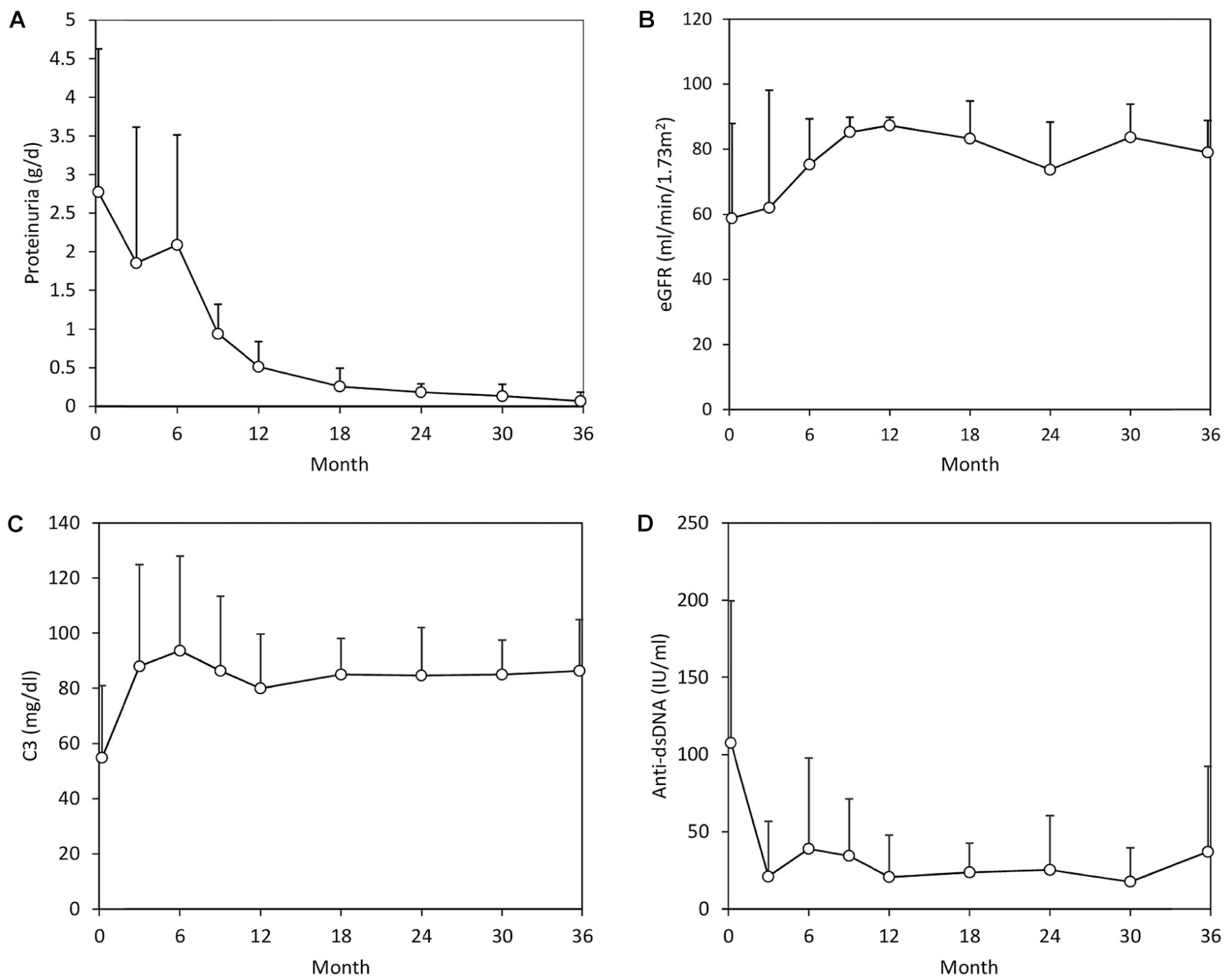

Figure 1. Longitudinal changes in (A) proteinuria, (B) eGFR, (C) serum C3 level, and (D) anti-dsDNA level in 5 patients who received prednisolone and sirolimus as initial therapy for active lupus nephritis. eGFR: estimated glomerular filtration rate.

quiescence, proteinuria remained at a low level and there was no significant change over time $(0.8 \pm 0.7 \mathrm{~g} / \mathrm{day}, 0.2 \pm 0.2$ $\mathrm{g} /$ day, $0.1 \pm 0.1 \mathrm{~g} /$ day, $0.3 \pm 0.2 \mathrm{~g} / \mathrm{day}$, and $0.7 \pm 0.7 \mathrm{~g} / \mathrm{day}$ at commencement of sirolimus and after $6,12,24$, and 36 months of treatment; $\mathrm{p}=0.316,0.328$, and 0.252 compared with baseline, respectively, Figure 2A). After sirolimus treatment, eGFR also remained stable $(58.6 \pm 25.8$ $\mathrm{ml} / \mathrm{min} / 1.73 \mathrm{~m}^{2}, 64.0 \pm 28.9 \mathrm{ml} / \mathrm{min} / 1.73 \mathrm{~m}^{2}, 60.7 \pm 30.0$ $\mathrm{ml} / \mathrm{min} / 1.73 \mathrm{~m}^{2}, 65.0 \pm 28.8 \mathrm{ml} / \mathrm{min} / 1.73 \mathrm{~m}^{2}$, and $63.0 \pm 29.6$ $\mathrm{ml} / \mathrm{min} / 1.73 \mathrm{~m}^{2}$ at commencement of sirolimus and after 6 , 12,24 , and 36 months of treatment; $p=0.618,0.071$, and 0.239 compared with baseline, respectively; Figure 2B). One patient developed endstage renal failure during followup. She had a serum creatinine level of $244 \mu \mathrm{mol} / 1$ (eGFR 18 $\mathrm{ml} / \mathrm{min} / 1.73 \mathrm{~m}^{2}$ ) when she began sirolimus, and required dialysis 27 months later.
Serological variables and disease flare. In patients with active $\mathrm{LN}$ who were treated with PSL and sirolimus, their $\mathrm{C} 3$ level increased over time $(54.8 \pm 26.1 \mathrm{mg} / \mathrm{dl}, 93.7 \pm 34.3 \mathrm{mg} / \mathrm{dl}$, $80.0 \pm 19.7 \mathrm{mg} / \mathrm{dl}, 84.7 \pm 17.4 \mathrm{mg} / \mathrm{dl}$, and $86.3 \pm 18.6 \mathrm{mg} / \mathrm{dl}$ at baseline and after $6,12,24$, and 36 months of treatment; $\mathrm{p}=0.148,0.100,0.077$, and 0.081 compared with baseline, respectively, Figure 1C). Their anti-dsDNA levels decreased over time $(107.7 \pm 91.9 \mathrm{IU} / \mathrm{ml}, 39.0 \pm 58.9 \mathrm{IU} / \mathrm{ml}, 20.7 \pm 27.1$ $\mathrm{IU} / \mathrm{ml}, 25.3 \pm 35.2 \mathrm{IU} / \mathrm{ml}$, and $37.0 \pm 55.4 \mathrm{IU} / \mathrm{ml}$ at baseline and after $6,12,24$, and 36 months, respectively; $\mathrm{p}=0.184$, $0.146,0.152$, and 0.178 compared with baseline, respectively; Figure 1D), though the differences did not reach statistical significance owing to the marked individual variations.

In patients who were treated with sirolimus during disease quiescence, there was a significant increase in serum C3 levels after 6 months of treatment, which was sustained over 

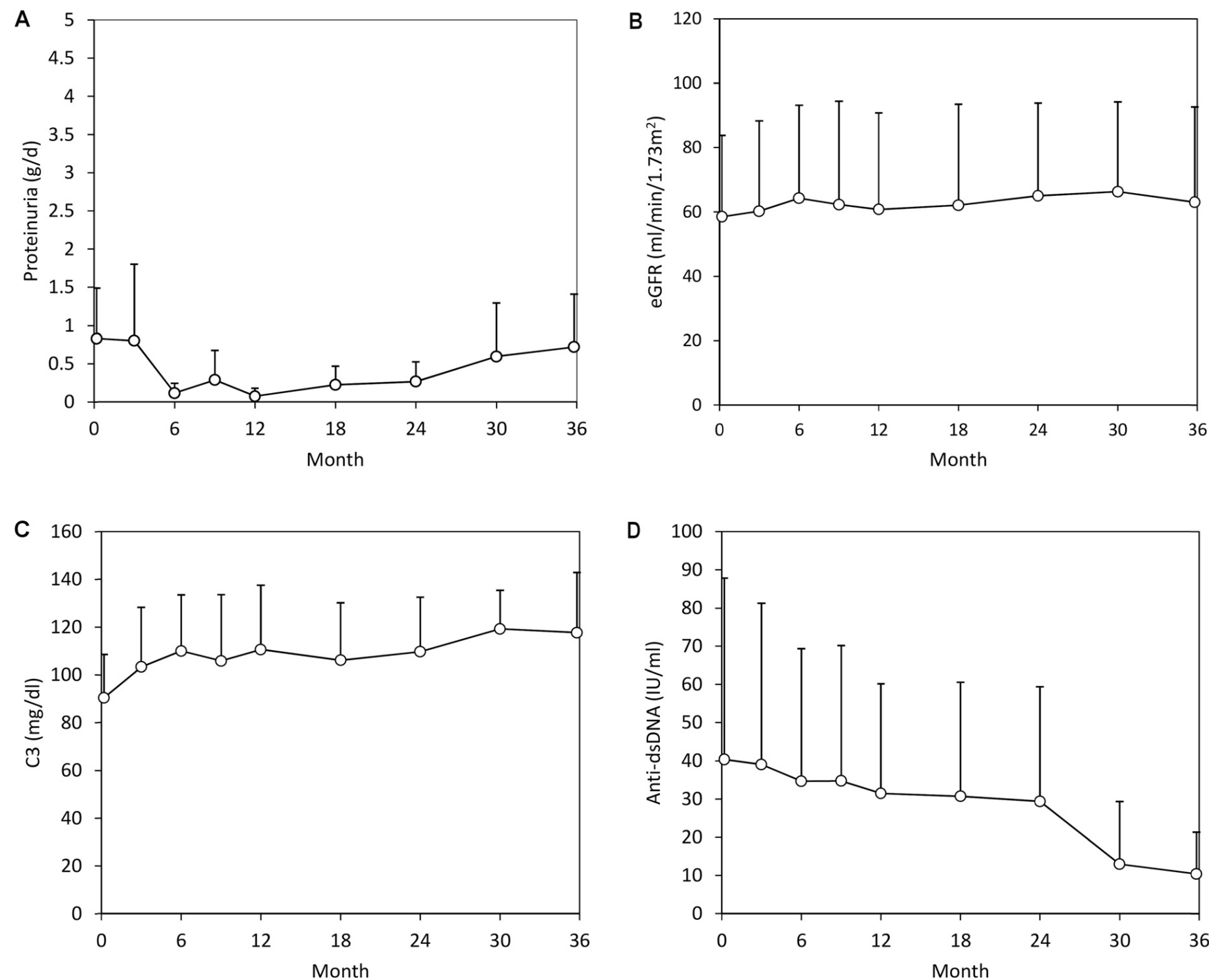

Figure 2. Longitudinal changes in (A) proteinuria, (B) eGFR, (C) serum C3 level, and (D) anti-dsDNA level in 11 patients who receive prednisolone and sirolimus as maintenance immunosuppression during quiescent disease. eGFR: estimated glomerular filtration rate.

36 months $(90.4 \pm 18.1 \mathrm{mg} / \mathrm{dl}, 110.0 \pm 23.6 \mathrm{mg} / \mathrm{dl}$, $110.6 \pm 26.9 \mathrm{mg} / \mathrm{dl}, 109.7 \pm 22.9 \mathrm{mg} / \mathrm{dl}$, and $117.7 \pm 25.1$ $\mathrm{mg} / \mathrm{dl}$ at commencement of sirolimus and after $6,12,24$, and 36 months, respectively; $\mathrm{p}=0.018,0.009,0.001$, and 0.025 compared with baseline, respectively; Figure 2C). Anti-dsDNA titer was significantly lower after 6 months and remained low afterward $(40.4 \pm 47.4 \mathrm{IU} / \mathrm{ml}, 34.7 \pm 34.7$ $\mathrm{IU} / \mathrm{ml}, 31.5 \pm 28.7 \mathrm{IU} / \mathrm{ml}, 29.4 \pm 30.0 \mathrm{IU} / \mathrm{ml}$, and $10.4 \pm 10.9$ $\mathrm{IU} / \mathrm{ml}$ at baseline and after $6,12,24$, and 36 months, respectively; $\mathrm{p}=0.031,0.086,0.071$, and 0.324 compared with baseline; Figure 2D). One patient had renal relapse, which occurred at 36 months after treatment. The dose of PSL was $9 \mathrm{mg} / \mathrm{day}$ and the 12-h trough sirolimus level was $2.6 \mu \mathrm{g} / \mathrm{l}$ when renal relapse occurred. One patient developed hematological flare (thrombocytopenia) while receiving prednisolone at $12.5 \mathrm{mg} /$ day with 12 -h trough sirolimus level at $2.9 \mu \mathrm{g} / \mathrm{l}$, and responded to an increased dose of PSL.
Adverse events. The adverse events experienced by patients with LN who had received prednisolone and sirolimus treatment were summarized (Table 3 ). Sirolimus was discontinued in 5 patients after $2.6 \pm 0.8$ months of treatment. Drug discontinuation was due to rash in 2 patients, leukopenia in 2 patients, headache in 1 patient, and the occurrence of acute cholecystitis in 1 patient. Worsening of lipid profile occurred in 4 patients, but all were adequately controlled with statins. The LDL/triglyceride levels were $2.8 \pm 0.8 / 1.4 \pm 0.9 \mathrm{mmol} / \mathrm{l}$, $2.6 \pm 0.3 / 1.2 \pm 0.5 \mathrm{mmol} / 1,3.0 \pm 0.4 / 1.3 \pm 0.6 \mathrm{mmol} / \mathrm{l}$, $2.7 \pm 0.7 / 1.0 \pm 0.26 \mathrm{mmol} / \mathrm{l}$, and $2.4 \pm 0.7 / 0.9 \pm 0.2 \mathrm{mmol} / 1$ at baseline and after $6,12,24$, and 36 months, respectively $(\mathrm{p}=0.346 / 0.313,0.651 / 0.175,0.465 / 0.314$, and $0.896 / 0.427$ compared with baseline, respectively). Three patients had infections ( 1 with acute cholecystitis, 1 with herpes zoster, and 1 with urinary tract infection) during followup and all responded to treatment. Leukopenia occurred in 2 patients

Personal non-commercial use only. The Journal of Rheumatology Copyright (C) 2018. All rights reserved. 
Table 3. Adverse events experienced by 16 patients with lupus nephritis who had received prednisolone and sirolimus treatment.

\begin{tabular}{lc}
\hline Adverse Events & Incidence \\
\hline New onset or worsening of hyperlipidemia & $4(25)$ \\
Hematological abnormalities & $3(18.8)$ \\
$\quad$ Leukopenia & $2(12.5)$ \\
$\quad$ Pancytopenia & $1(6.2)$ \\
Infection & $3(18.8)$ \\
$\quad$ Acute cholecystitis & $1(6.2)$ \\
Urinary tract infection & $1(6.2)$ \\
$\quad$ Herpes zoster & $1(6.2)$ \\
Aphthous ulcer & $2(12.5)$ \\
Rash & $2(12.5)$ \\
Headache & $1(6.2)$ \\
\hline
\end{tabular}

Data are $n(\%)$

(corresponding 12-h trough levels were $3.2 \mu \mathrm{g} / \mathrm{l}$ and $7.6 \mu \mathrm{g} / \mathrm{l}$, respectively) and were not associated with infective complications. The white cell count normalized spontaneously in the first patient and after discontinuation of sirolimus in the second patient. The patient with acute cholecystitis also developed pancytopenia (corresponding 12-h trough level was $7.7 \mu \mathrm{g} / \mathrm{l}$ ), and the blood counts recovered after stopping sirolimus and treatment of infection.

\section{DISCUSSION}

Our data suggested that sirolimus could serve as an alternative treatment for patients with $\mathrm{LN}$ who cannot tolerate standard immunosuppressants or have a history of malignancy. The preliminary data suggest efficacy when given with corticosteroids, and side effects did not appear excessive. The advantage of mTOR inhibitors was that they were nonnephrotoxic, except when given with calcineurin inhibitors, when they could increase the risk of nephrotoxicity $^{23}$. However, data from kidney transplant recipients suggested that mTOR inhibitors might induce proteinuria because of their action on glomerular podocytes and renal tubular cells, and a significant increase in proteinuria after mTOR inhibitor treatment was associated with inferior renal allograft outcome $24,25,26,27$. Our data show that in patients given PSL and sirolimus for the treatment of active LN, proteinuria decreased while renal function improved. In patients who received low-dose PSL and sirolimus as longterm maintenance immunosuppression, proteinuria remained low and there was no significant change over time. These results do not suggest a significant risk of sirolimus in inducing or aggravating proteinuria, with prolonged treatment lasting $45.3 \pm 36.5$ months. The progression to endstage renal failure after 27 months in 1 patient was attributed to underlying chronic renal damage rather than the untoward effect of treatment.

We also observed relatively favorable longterm disease stability in patients receiving low-dose PSL and sirolimus maintenance. Renal relapse occurred in only 1 patient and immune thrombocytopenia occurred in another patient, and both episodes were associated with low 12-h trough sirolimus level. The potential contribution of sirolimus on longterm disease stability was also corroborated by the improvement in serological variables after the initiation of sirolimus. The immunological effects of sirolimus on disease mechanisms in $\mathrm{LN}$ require further investigation. Possible mechanisms leading to a reduction of disease activity include reduction of intrarenal lymphoproliferation and MCP-1 expression, suppression of anti-dsDNA production and immune deposition, reversal of senescent phenotype of bone marrowderived mesenchymal cells, promotion of Treg expansion, and blockade of Th17 expansion ${ }^{16,17,18,28,29,30,31}$. Further, the results from animal experiments and human kidney biopsies demonstrating activation of the mTOR pathway during active nephritis, and the therapeutic effect of mTOR inhibitor in murine SLE, provide a strong rationale for testing the effect of mTOR inhibitors in the treatment of human $\mathrm{LN}^{16,17}$. In this regard, previous studies have shown that mTOR activity was increased in SLE T cells, and rapamycin treatment reversed $\mathrm{T}$ cell receptor- $\zeta$ deficiency and Fce-R1 $\gamma$ upregulation, which underlies aberrant $\mathrm{T}$ cell activation and death pathway selection in $\mathrm{SLE}^{32}$. One limitation of our study was that we did not investigate the effect of treatment on mTOR activity in the T cells of our patients with $\mathrm{LN}$.

In our study, all patients received sirolimus treatment either because of intolerance to standard immunosuppressants or a history of malignancy. In the former group, the side effects due to their previous immunosuppressants resolved in all except 1 patient after conversion to sirolimus. In the latter group, there was no tumor recurrence after a followup of $54.0 \pm 16.9$ months. Increased longterm risk of malignancy had been reported in patients with LN and was associated with excessive mortality $1,33,34$. Data from organ transplant recipients show that longterm immunosuppressive regimens that include mTOR inhibitors are associated with reduced overall cancer risk when compared to patients not treated with mTOR inhibitors, and the difference is because of a lower incidence of nonmelanoma skin cancers and kidney cancers ${ }^{13,35,36}$. Also, sirolimus treatment has been associated with complete remission of Kaposi sarcoma and significant reduction in the risk of recurrent nonmelanocytic skin cancers ${ }^{13,35}$. In this context, sirolimus presents an attractive option for patients with $\mathrm{LN}$ who required prolonged maintenance immunosuppression and have a history of neoplastic disease.

In a recent prospective single-arm study, treatment with sirolimus for 12 months resulted in improvement in disease activity scores, reduction of concomitant corticosteroids dosage, expansion of Treg, and decreased Th17 cells in patients with active SLE without renal involvement ${ }^{37}$. While sirolimus may show efficacy in milder SLE cases without nephritis, the use of sirolimus as continuous induction-maintenance treatment is still exploratory owing to the

Personal non-commercial use only. The Journal of Rheumatology Copyright $\subset$ 2018 . All rights reserved. 
small number of patients. Two patients required discontinuation of sirolimus because of the occurrence of acute cholecystitis and leukopenia, respectively. The relationship of sirolimus to these adverse events is unclear because the patient who developed cholecystitis had preexisting gallstones and the other patient also had leukopenia before commencement of sirolimus. The other patients who tolerated PSL and sirolimus induction all showed significant improvements in proteinuria and serological variables, and such clinical responses were sustained over 36 months. These pilot results suggested that investigation of the use of sirolimus induction would be worthwhile in future clinical studies.

Side effects of sirolimus include dyslipidemia, oral ulcers, myelosuppression, impaired wound healing, and rarely, interstitial pneumonitis ${ }^{27,38}$. Oral ulceration may be severe enough to require drug discontinuation. This did not occur in our patients, probably because of the avoidance of high trough blood levels and prior advice on oral hygiene and the use of mouth gargle. These longterm results, albeit in a relatively small number of patients, suggest that sirolimus treatment is relatively well tolerated in patients with $\mathrm{LN}$. Deterioration of lipid profile was the most frequently observed adverse event in this cohort, but all cases were adequately controlled with statins. Myelosuppression occurred in 3 patients. While the patients with pancytopenia also had acute cholecystitis, the other 2 episodes of leukopenia were not associated with infective complications. While our pilot experience suggests that sirolimus in combination with corticosteroids appears efficacious and relatively well tolerated, it would also be worthwhile to compare longterm effects of sirolimus with conventional therapies on a case-control basis.

These preliminary results suggest that sirolimus combined with PSL appears effective and relatively well tolerated in patients with LN, and could be considered a possible alternative treatment for active or quiescent LN, especially in patients who have a history of malignancy or who cannot tolerate standard immunosuppressive medications.

\section{REFERENCES}

1. Yap DY, Tang CS, Ma MK, Lam MF, Chan TM. Survival analysis and causes of mortality in patients with lupus nephritis. Nephrol Dial Transplant 2012;27:3248-54.

2. Saxena R, Mahajan T, Mohan C. Lupus nephritis: current update. Arthritis Res Ther 2011;13:240.

3. Jakes RW, Bae SC, Louthrenoo W, Mok CC, Navarra SV, Kwon N. Systematic review of the epidemiology of systemic lupus erythematosus in the Asia-Pacific region: prevalence, incidence, clinical features, and mortality. Arthritis Care Res 2012;64:159-68.

4. Hahn BH, McMahon MA, Wilkinson A, Wallace WD, Daikh DI, Fitzgerald JD, et al. American College of Rheumatology guidelines for screening, treatment, and management of lupus nephritis. Arthritis Care Res 2012;64:797-808.

5. Bertsias GK, Tektonidou M, Amoura Z, Aringer M, Bajema I, Berden JH, et al. Joint European League Against Rheumatism and European Renal Association-European Dialysis and Transplant
Association (EULAR/ERA-EDTA) recommendations for the management of adult and paediatric lupus nephritis. Ann Rheum Dis 2012;71:1771-82.

6. Kidney Disease: Improving Global Outcomes (KDIGO) Glomerulonephritis Work Group. KDIGO clinical practice guidelines for glomerulonephritis. Kidney Int Suppl 2012; 2:139-274.

7. Mok CC, Yap DY, Navarra SV, Liu ZH, Zhao MH, Lu L, et al. Overview of lupus nephritis management guidelines and perspective from Asia. Nephrology 2014;19:11-20.

8. Chan TM, Tse KC, Tang CS, Mok MY, Li FK. Long-term study of mycophenolate mofetil as continuous induction and maintenance treatment for diffuse proliferative lupus nephritis. J Am Soc Nephrol 2005; $16: 1076-84$

9. Austin HA 3rd, Illei GG, Braun MJ, Balow JE. Randomized, controlled trial of prednisone, cyclophosphamide, and cyclosporine in lupus membranous nephropathy. J Am Soc Nephrol 2009;20:901-11.

10. Illei GG, Austin HA, Crane M, Collins L, Gourley MF, Yarboro CH, et al. Combination therapy with pulse cyclophosphamide plus pulse methylprednisolone improves long-term renal outcome without adding toxicity in patients with lupus nephritis. Ann Intern Med 2001;135:248-57.

11. Chan TM, Li FK, Tang CS, Wong RW, Fang GX, Ji YL, et al. Efficacy of mycophenolate mofetil in patients with diffuse proliferative lupus nephritis. Hong Kong-Guangzhou Nephrology Study Group. N Engl J Med 2000;343:1156-62.

12. Yap DY, Ma MK, Mok MM, Tang CS, Chan TM. Long-term data on corticosteroids and mycophenolate mofetil treatment in lupus nephritis. Rheumatology 2013;52:480-6.

13. Fantus D, Rogers NM, Grahammer F, Huber TB, Thomson AW. Roles of mTOR complexes in the kidney: implications for renal disease and transplantation. Nat Rev Nephrol 2016;12:587-609.

14. Ekberg H, Tedesco-Silva H, Demirbas A, Vitko S, Nashan B, Gurkan A, et al. Reduced exposure to calcineurin inhibitors in renal transplantation. N Engl J Med 2007;357:2562-75.

15. Schena FP, Pascoe MD, Alberu J, del Carmen Rial M, Oberbauer R, Brennan DC, et al. Conversion from calcineurin inhibitors to sirolimus maintenance therapy in renal allograft recipients: 24-month efficacy and safety results from the CONVERT trial. Transplantation 2009;87:233-42.

16. Lui SL, Yung S, Tsang R, Zhang F, Chan KW, Tam S, et al. Rapamycin prevents the development of nephritis in lupus-prone NZB/W F1 mice. Lupus 2008;17:305-13.

17. Lui SL, Tsang R, Chan KW, Zhang F, Tam S, Yung S, et al. Rapamycin attenuates the severity of established nephritis in lupus-prone NZB/W F1 mice. Nephrol Dial Transplant 2008;23:2768-76

18. Alperovich G, Rama I, Lloberas N, Franquesa M, Poveda R, Goma $\mathrm{M}$, et al. New immunosuppresor strategies in the treatment of murine lupus nephritis. Lupus 2007;16:18-24.

19. Warner LM, Adams LM, Sehgal SN. Rapamycin prolongs survival and arrests pathophysiologic changes in murine systemic lupus erythematosus. Arthritis Rheum 1994;37:289-97.

20. Fernandez D, Bonilla E, Mirza N, Niland B, Perl A. Rapamycin reduces disease activity and normalizes $\mathrm{T}$ cell activation-induced calcium fluxing in patients with systemic lupus erythematosus. Arthritis Rheum 2006;54:2983-8.

21. Yap DY, Ma MK, Tang CS, Chan TM. Proliferation signal inhibitors in the treatment of lupus nephritis: preliminary experience. Nephrology 2012;17:676-80.

22. Yap DY, Ma MK, Mok MM, Kwan LP, Chan GC, Chan TM. Long-term data on tacrolimus treatment in lupus nephritis. Rheumatology 2014;53:2232-7.

23. Podder H, Stepkowski SM, Napoli K, Kahan BD. Pharmacokinetic interactions between sirolimus and cyclosporine exacerbate renal

Personal non-commercial use only. The Journal of Rheumatology Copyright $\odot$ 2018. All rights reserved 
dysfunction. Transplant Proc 2001;33:1086.

24. Stylianou K, Petrakis I, Mavroeidi V, Stratakis S, Kokologiannakis $\mathrm{G}$, Lioudaki E, et al. Rapamycin induced ultrastructural and molecular alterations in glomerular podocytes in healthy mice. Nephrol Dial Transplant 2012;27:3141-8.

25. Diekmann F, Andres A, Oppenheimer F. mTOR inhibitor-associated proteinuria in kidney transplant recipients. Transplantation Rev 2012;26:27-9.

26. Ponticelli C, Graziani G. Proteinuria after kidney transplantation. Transpl Int 2012;25:909-17.

27. Morath C, Arns W, Schwenger V, Mehrabi A, Fonouni H, Schmidt J, et al. Sirolimus in renal transplantation. Nephrol Dial Transplant 2007;22 Suppl 8:viiii61-5.

28. Stylianou K, Petrakis I, Mavroeidi V, Stratakis S, Vardaki E, Perakis $\mathrm{K}$, et al. The PI3K/Akt/mTOR pathway is activated in murine lupus nephritis and downregulated by rapamycin. Nephrol Dial Transplant 2011;26:498-508.

29. Gu Z, Tan W, Ji J, Feng G, Meng Y, Da Z, et al. Rapamycin reverses the senescent phenotype and improves immunoregulation of mesenchymal stem cells from MRL/lpr mice and systemic lupus erythematosus patients through inhibition of the mTOR signaling pathway. Aging 2016;8:1102-14.

30. Lai ZW, Borsuk R, Shadakshari A, Yu J, Dawood M, Garcia R, et al. Mechanistic target of rapamycin activation triggers IL-4 production and necrotic death of double-negative T cells in patients with systemic lupus erythematosus. J Immunol 2013;191:2236-46.

31. Kato H, Perl A. Mechanistic target of rapamycin complex 1 expands
Th17 and IL-4+ CD4-CD8- double-negative T cells and contracts regulatory $\mathrm{T}$ cells in systemic lupus erythematosus. J Immunol 2014;192:4134-44.

32. Fernandez DR, Telarico T, Bonilla E, Li Q, Banerjee S, Middleton FA, et al. Activation of mammalian target of rapamycin controls the loss of TCRzeta in lupus T cells through HRES-1/Rab4-regulated lysosomal degradation. J Immunol 2009;182:2063-73.

33. Bernatsky S, Boivin JF, Joseph L, Rajan R, Zoma A, Manzi S, et al. An international cohort study of cancer in systemic lupus erythematosus. Arthritis Rheum 2005;52:1481-90.

34. Bernatsky S, Joseph L, Boivin JF, Gordon C, Urowitz M, Gladman $\mathrm{D}$, et al. The relationship between cancer and medication exposures in systemic lupus erythaematosus: a case-cohort study. Ann Rheum Dis 2008;67:74-9.

35. Yanik EL, Siddiqui K, Engels EA. Sirolimus effects on cancer incidence after kidney transplantation: a meta-analysis. Cancer Med 2015;4:1448-59.

36. Yanik EL, Gustafson SK, Kasiske BL, Israni AK, Snyder JJ, Hess GP, et al. Sirolimus use and cancer incidence among US kidney transplant recipients. Am J Transplant 2015;15:129-36.

37. Lai ZW, Kelly R, Winans T, Marchena I, Shadakshari A, Yu J, et al. Sirolimus in patients with clinically active systemic lupus erythematosus resistant to, or intolerant of, conventional medications: a single-arm, open-label, phase $1 / 2$ trial. Lancet 2018;391:1186-96.

38. Merkel S, Mogilevskaja N, Mengel M, Haller H, Schwarz A. Side effects of sirolimus. Transplant Proc 2006;38:714-5. 